\title{
Plant Cells in the Context of Climate Change
}

\author{
Marcelo Rubens Machado* \\ Programa de Pós-Graduação em Biologia Celular e Estrutural; Departamento de Biologia Celular; Instituto de \\ Biologia; Universidade Estadual de Campinas; Campinas - SP - Brasil
}

\begin{abstract}
Global warming and its origins triggered the beginning to considerable discussion in the last century. Studies of climate models presented in multidisciplinary scientific reports suggest that anthropogenic activities, particularly the emission of gases from the greenhouse effect, are greatly responsible for the current climate changes. The increase of carbon dioxide $\left(\mathrm{CO}_{2}\right)$ atmospheric concentration has been in discussion in the news, scientific meetings and in public policy debates in several countries. Apart from its impact on global warming, the rising atmospheric $\mathrm{CO}_{2}$ has alerted the scientific community to the need to investigate any morpho-physiological alterations in the plants, given their direct influence on photosynthesis. This article aims to discuss cellular aspects related to plant growth, their behavior of cuticular waxes and the responses of the stomatal development arising from the chemical change to the atmosphere, which are the causes of serious concern and discussion.
\end{abstract}

Key words: Carbon dioxide, Global warming, Stomata, Climate change biology, Plant cell, Waxes

\section{INTRODUCTION}

The expression 'global warming' has appeared frequently in the press, alarming laypeople and specialists alike, despite the fact that scientists have been warning this problem since the $17^{\text {th }}$ century. In the political sphere, the issue was discussed during the first World Climate Conference, in Geneva, Switzerland in 1979, which was followed a decade later with the signature of the UN convention on climate change; Eco-92 in Rio de Janeiro; and in 1997 with the negotiation of the Kyoto Protocol (Kandel 2002).

By definition, 'climate' and 'climate system' are different. The climate system is more complex and interactive, as it consists of elements present in the atmosphere on the Earth's surface and in the bodies of water, as well as the organisms that inhabit the planet. The climate is usually described as variables of temperature, precipitation and the dynamics of winds over a period that can be of months to millions of years. In this manner, the climate system suffers from the influence of its own internal dynamic as well as external factors forcings -, which include natural phenomena such as volcanic eruptions and solar variations, as well as changes in the atmospheric composition induced by human activities. Solar radiation acts on the climate system with three basic mechanisms: changes in the Earth's orbit, changes in the radiation reflected from the Earth's surface (albedo), and changes in the concentration of greenhouse gases, which modify the wave length of the radiation reflected from Earth back to the space. If the Earth was to reflect all the energy that it receives from the sun, its surface would have an average temperature of $-19^{\circ} \mathrm{C}$, quite different from the average that we know $\left(+14^{\circ} \mathrm{C}\right)$. The reason for this difference is due to the presence of gases that act by partially blocking the energy reflected by

*Author for correspondence: balosp@bol.com.br 
the surface, preventing it from returning to the space. This is called the "greenhouse effect" and its most important elements are carbon dioxide $\left(\mathrm{CO}_{2}\right)$ and water vapor (Le Treut et al. 2007; Newman et al. 2010).

The atmospheric $\mathrm{CO}_{2}$ concentration has strongly increased since the start of industrialization in response to, probably, anthropogenic emissions and reached a level which is unprecedented in the history. The present $\mathrm{CO}_{2}$ concentration amounts to about $390 \mathrm{ppm}$ (parts per million) as opposed to a pre-industrial concentration of $280 \mathrm{ppm}$. Carbon dioxide is a greenhouse gas and known to warm the Earth's surface, as it is transparent for the short-wave solar but not for some of the longwave infrared radiation emitted by the Earth's surface (Latif 2011). Another important component is clouds, which absorb infrared radiation emitted by the Earth, warming the planet, but also absorb ultraviolet radiation from the sun, contributing to the cooling of the planet. Changes to the aspects of clouds such as type, location, water content, altitude, particle size and shape affect the degree to which the clouds heat, or cool the Earth's surface. This alerts us to the complexity of the subject and reinforces the need to do more studies to better understand it (Forster et al. 2007).

Human activities have intensified the effect of these gases when raising the concentration of some of their components (Buckeridge and Aidar 2002), mainly since the advent of the industrial age in the $18^{\text {th }}$ century (Fig. 1). Models of climate reconstruction over long periods (Fig. 2) indicate that the planet really is hotter. This increase is primarily due to the burning of fossil fuel based energy and deforestation, which have modified the chemical composition of the atmosphere with substantial implication on the global climate system (Hugues 2000).

Beyond $\mathrm{CO}_{2}$ and water vapor, other important elements that cause the greenhouse effect are methane $\left(\mathrm{CH}_{4}\right)$, nitrous oxide $\left(\mathrm{N}_{2} \mathrm{O}\right)$ and the chlorofluorocarbons (CFCs), gases with high potential for global warming. The concentration of carbon dioxide predicted for the year 2100 was from $540 \mathrm{ppm}$ to $970 \mathrm{ppm}$, a significant increase if compared with $280 \mathrm{ppm}$ from the pre-industrial period and $368 \mathrm{ppm}$ for the year 2000 . However, uncertain scenarios, such as the persistence of the deforestation process and the magnitude of climate feedback in the biosphere, cause variation in the $\mathrm{CO}_{2}$ concentration estimate for the year 2100 , between 490 and $1260 \mathrm{ppm}$ (75 to 350\% increase in relation to the pre-industrial era) (Gitay et al. 2002). The forecasts indicated values near 720 ppm halfway through the $21^{\text {st }}$ century (Prentice 2001).

The observation that the atmosphere acts as a greenhouse, allowing the radiation to penetrate while preserving part of the heat, was noted in $17^{\text {th }}$ century by Edme Mariotte. Two centuries later, in 1859, John Tyndall noticed that the changes in the concentration of atmospheric components, such as $\mathrm{CO}_{2}$ and water, could produce climate changes, which had been cited in previous geological studies. In 1895, Swedish chemist Svante Arrhenius observed that increased fossil fuel combustion (coal, gas and oil) would increase the amount of $\mathrm{CO}_{2}$ in the atmosphere, and then formulated the hypothesis that it would increase the greenhouse effect and would cause re-warming of the Earth's surface. In 1938, by means of mathematical calculations, Callendar claimed that by doubling the atmospheric concentration of $\mathrm{CO}_{2}$, the global temperature average would go up $2^{\circ} \mathrm{C}$, with considerable warming of the polar regions. $\mathrm{He}$ associated this rising $\mathrm{CO}_{2}$ to fossil fuel burning and its greenhouse effect. In 1957 Charles David Keeling initiated a long series of systematic and precise measurements of atmospheric $\mathrm{CO}_{2}$ concentration, confirming the Arrhenius' hypothesis. The annual average gas concentration changed from $315 \mathrm{ppm}$ in 1958 to $330 \mathrm{ppm}$ in 1974. Since 2001 the average $\mathrm{CO}_{2}$ concentration has exceeded $370 \mathrm{ppm}$ (Le Treut et al. 2007).

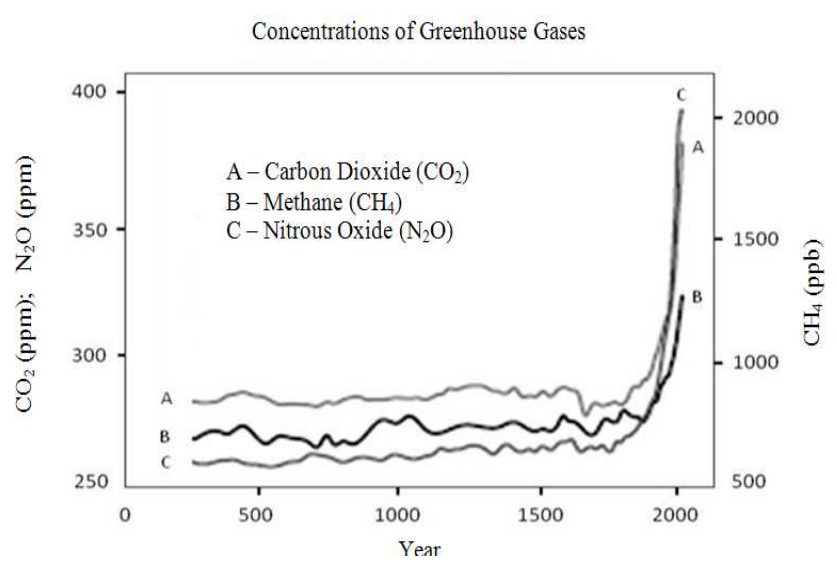

Figure 1 - Atmospheric concentration of gases significant to the greenhouse effect in the last 2000 years. Increases registered since 1750 are attributed to human activities from the industrial era (Forster et al. 2007). 


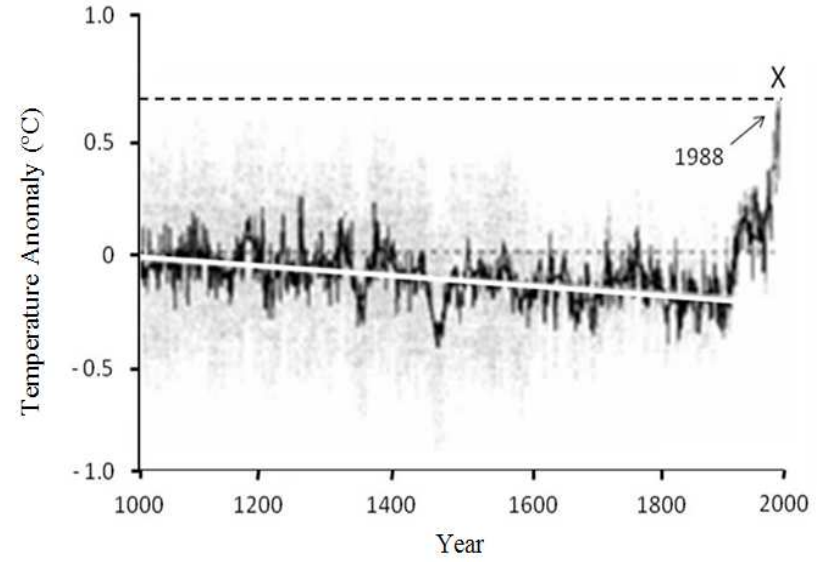

Figure 2 - Reconstruction of the average annual temperature of the Earth's surface in the northern hemisphere in the last millenium. Linear trend (white line) between the years 1000 and 1850. The gray area represents the standard error (Hugues 2000).

In accordance with projections from the Intergovernmental Panel of Climate Changes (IPCC), created by the UN in 1988, the increase of the average temperature of Earth's surface to 2100 will be between 1.4 and $5.7^{\circ} \mathrm{C}$. If this forecast is confirmed, Earth will experience radical changes as those which ended the last glacial period. However, this period of natural changes can took thousands of years to happen, the warming currently observed may occur in over one century. One of the reasons for causing this accelerated warming is human activity, such as population growth, deforestation in the tropics, expansion of agricultural and livestock activities, increase in urban and industrial areas, among others (Kandel 2002). In policy meetings, the previous United States Government questioned human participation in the Earth's recent climate warming. However, the EPA (Environmental Protection Agency) warn that human activities, especially industrial emissions, have changed the atmosphere's composition and influencing Earth's climate, even when considering the natural phenomena such as volcanic eruptions which also contributed to this process (EPA 2012).

In a recent study using annual series (1980 to 2004) of $\mathrm{CO}_{2}$ emission, primary energy consumption, population growth and wealth increase in the countries including USA, Japan, China, India, countries from the European
Community and others, Raupach et al. (2007) reported that the $\mathrm{CO}_{2}$ emissions forecasted in the IPCC reports were underestimated. The gas emission rate grew from $1.1 \%$ per year during the 1990 's to more than $3 \%$ per year (more than 2 $\mathrm{ppm} /$ year) between 2000 and 2004. This growth, observed in less developed and developing countries, such as China, was caused by significant economic expansion, meaning larger income per capita and GDP (Gross Domestic Product), and further sustained by a demand for energy based on fossil fuels. Another observation was that developing countries as well as developed had increased their $\mathrm{CO}_{2}$ emissions, and that, therefore, no region was "decarbonizing" its energy matrix, in spite of all the warnings from the scientific community.

\section{The effect of high $\mathrm{CO}_{2}$ on plants}

The evidence that the increase of atmospheric concentration of greenhouse gases, especially $\mathrm{CO}_{2}$ will have an effect on Earth's climate has resulted in efforts from various scientific areas. Climate researchers seek to identify if the current changes are caused by the human activities, or natural variables, and in this manner, try to forecast future climate scenarios. For ecologists and physiologists, the challenge is to predict the effect of these changes on the species and communities, since alterations in $\mathrm{CO}_{2}$ concentration, temperature and rain cycles can directly affect the biological processes such as photosynthesis, respiration, growth and the composition of plant tissues. Nor are effects on the distribution of species and phenology discarded. These changes, if confirmed, would inevitably modify the competition and interaction among the species (Hugues 2000).

Several components of the climate system, including the oceans and biota, affect the atmospheric concentrations of greenhouse gases. Plants are important examples as they remove the $\mathrm{CO}_{2}$ from the atmosphere and, when water is present, convert it into carbohydrates. Photosynthesis and, consequently, the growth and productivity, are directly affected by the $\mathrm{CO}_{2}$, which seems to exert a fertilizing effect on the plants. This effect is more evident in the species from the temperate climates, such as conifers, where the fixed carbon is primarily allocated in vascular exchange. However, in the tropical species, eventual biomass increases are more distributed by the plant (Phillips et al. 1998). 
The direct effects of atmospheric $\mathrm{CO}_{2}$ on the photosynthetic activities and the use of the water are widely known (Jarvis et al. 1999; Teng et al. 2006). In this manner, the increase in the concentration of the $\mathrm{CO}_{2}$ will potentially affect the vegetation and the ecosystems of the forests (Souza et al. 2010) as well as farm land. To investigate plant responses, therefore, it is essential to analyze the plant responses for understanding the effects of global changes. Samples from the herbariums and plant fossils (Paleobotany) can provide an indication of the atmosphere from other centuries and geological eras, respectively. Registers obtained from air bubbles trapped in the polar ice, particularly in Antarctica, have shown that the $\mathrm{CO}_{2}$ atmospheric concentration oscillated between 180 and $280 \mathrm{ppm}$ in cycles of one hundred thousand years. The studies that determine the gas concentration from the paleoatmosphere are divided into two groups. The first is based on the geochemical modeling of the carbon cycle in millions of years, through volcanism and tectonics. The second uses the geochemical and paleobiological indicators in which segments from the plant fossils are used to estimate millennium levels of $\mathrm{CO}_{2}$. Herbarium samples permit to predict if the atmosphere from the pre-industrial period, admittedly with lower concentration of $\mathrm{CO}_{2}$, modified plant aspects, such as the number of stomata on the leaves, for example. They are, therefore, methods to study the climate of periods from the past (Beerling and Royer 2002). A critical and important review about the ability of biological palaeoproxies in predicting past climate and levels of atmospheric $\mathrm{CO}_{2}$ from fossil leaves has been presented by Jordan (2011). It provides a critical framework for an understanding of the uncertainties of quantitative fossil-based proxies of past environments, and considers in detail the use of foliar physiognomy (i.e., gross morphology of fossil leaves and the relative frequency of stomata on leaves) to estimate the mean annual temperature and past levels of atmospheric $\mathrm{CO}_{2}$, respectively. Another important approach of paleobotany and climate proxies has been presented by Peppe et al. (2011).

Some methodological approaches have been applied since the studies on the effects of elevated atmospheric $\mathrm{CO}_{2}$ concentration on the plants began. Initially, only species of economic interest, especially vegetables, were submitted to special growth conditions. With the evolution of the chamber system, the trees species were examined in the experiments with controlled environmental parameters (Ceulemans and Mousseau 1994). These structures, however, limited the study of adult trees and forest areas, though it was partially resolved with a technique that individually submitted the adult tree branches to established and controlled conditions. The so-called branch bag technique encloses a tree branch in a bag, inside which environmental conditions such as $\mathrm{CO}_{2}$ concentration and temperature can be controlled. The theory of branch autonomy in relation to the plant is assumed to be valid (Sprugel et al. 1991), albeit questionable, especially when considering the deciduous species. The FACE system (Free-Air $\mathrm{CO}_{2}$ Enrichment), another method of study, was developed to exclude the limitations of the previous systems (relative soil differences, for example), and to submit the plant groups to high $\mathrm{CO}_{2}$ for long periods over multiple seasons and, in the case of crops, over their entire lifetime (Leakey et al. 2009; Pinkard et al. 2010). However, the investment cost and maintenance are very expensive (Okada et al. 2001), which can make its application unviable. The open top chambers (OTCs), originally used in the atmospheric pollution studies, constitute the most common controlled atmosphere system, despite the necessity to consider differences related to temperature, relative humidity and winds.

\section{Physiology and growth}

Many physiological data have been obtained from the studies such as those described above. In trees species exposed to elevated $\mathrm{CO}_{2}$, a general trend of increased growth was observed, due to an extra intake of assimilate distributed in different plant structures, driving the modifications in root/aerial part ratio (Poorter 1993), and indicating a preference for extra storage in the roots in detriment to other plant tissues (Rogers et al. 1992). The larger investment in the roots seems to be a response to the need for greater acquisition of mineral nutrients in poor soil. However, Petterson et al. (1993) did not find an association between the high $\mathrm{CO}_{2}$ and differences in the dry mass of roots and stems in Birch pendula, while fine root growth in desert species was not increased by elevated $\mathrm{CO}_{2}$ over the long term (Ferguson and Nowak 2011).

The increase in photosynthesis rates and improved water relations, observed in the plants cultivated 
under an elevated $\mathrm{CO}_{2}$, normally generate biomass and height increases in the plants, 49 and $12 \%$, respectively higher than those cultivated in an atmosphere with ambient $\mathrm{CO}_{2}$ concentration (Ainsworth and Long 2005). Aidar et al. (2002), studying the seedlings from jatobá Hymenaea courbaril also found root:stem alterations due to changes in the biomass content of the different tissues, when the plants had been cultivated under elevated $\mathrm{CO}_{2}$. According to Lin et al. (2012), the response of photosynthesis to temperature is a central element of plant response to climate change, and such responses have been found to be highly variable among species and among studies. They quantified the relative contribution of three factors - (1) photosynthetic biochemistry, (2) respiration and (3) stomatal sensitivity, and concluded that each of the three processes was quantitatively important, suggesting that each needs to be quantified to be able to predict the temperature responses of photosynthesis.

Studies of alterations to the components of the cellular wall of the plants grown under an elevated $\mathrm{CO}_{2}$, especially the cellulose, are important because the accumulation of cellulose in the plants is a form of carbon kidnapping (Buckeridge and Aidar 2002). Aranda et al. (2006), studying oak trees, found significant differences in the cellulose content in the leaves, but they did not observe changes in lignin and hemicelluloses degrees. An increase in the cellulose content (approximately $33 \%$ in the leaves and 19\% in the stems) was also observed in jatobá seedlings grown in an atmosphere with $720 \mathrm{ppm}$ of $\mathrm{CO}_{2}$ (Gaspar and Buckeridge, data not published). In Arabidopsis leaves the increase of this composition was $22 \%$ (Teng et al. 2006).

Species exposed for long periods (weeks, or months) to elevated $\mathrm{CO}_{2}$ can acclimatize, reducing their photosynthesis. The concept that in this atmospheric condition the available amount of carbohydrates increases is prevalent. The plant responds to this increase in different ways, depending on its storage capacity. In certain species, the photosynthesizing capacity remains high during long periods of exposure to elevated $\mathrm{CO}_{2}$, given their genetic capacity to increase the size or number of some storage organs (Ceulemans and Mousseau 1994). New carbon drains, such as leaves, can appear, as in the case of Sylvatica fagus (El Kohen et al. 1993), but in other species there may be a model of genetically determined growth that leads it to the acclimatization process
(Mousseau and Enoch 1989). Smith and Stitt (2007) consider that acclimatization responses adjust the balance between carbon supply and consumption, coordinating the partition of the photosynthesis products, its rate of starch use in the dark and growth rate. The acclimatization responses would still permit adjustments in situations of environmental changes that limited carbon availability, in such a manner to optimize the plant growth. These responses require mechanisms that identify the available carbon level in the plant (sugar sensing), convert it into a metabolic signal, which, connected to the specific molecule, provokes a chain reaction that culminates in growth control and carbon balance.

\section{Morphological aspects}

Among the plant organs, the leaf has the maximum diversity, showing high structural plasticity in response to different environmental conditions. Its development is crucial to the plant because it is responsible for light interception, photosynthesis, water use and, above all, for the total productivity of the plant. In another context, anatomical, ultrastructural and biochemical characteristics of the leaves define the productivity index of a forest, which can be, therefore, impacted by increased $\mathrm{CO}_{2}$ in the atmosphere (Pritchard et al. 1999; Riikonen et al. 2010). Of the parameters used in investigating the potential effects of elevated $\mathrm{CO}_{2}$ on the plants, the leaf area is one of the most considered as it is an important component in determining the total productivity of plants, since light interception, related to photosynthesis, is also determined by the leaf area index (Ewert 2004). The growth of leaves involves cellular production and expansion, and it is possible that these two processes are influenced by an additional $\mathrm{CO}_{2}$ intake. However, the response does not seem to be unique to all the groups. Ranasinghe and Taylor (1996) found that the growth of the leaf area of Phaseolus vulgaris exposed to elevated $\mathrm{CO}_{2}$ occurred as a result of an increase of the cellular expansion, independent of the production of new cells. Gardner et al. (1995) reported the positive effect of high $\mathrm{CO}_{2}$ on the cellular expansion in Populus clones, but the size of the expanded epidermal leaf cells was not influenced by the elevated $\mathrm{CO}_{2}$, suggesting that the production of new cells could have contributed to leaf growth. Taylor et al. (1994) reported that the carbon, probably from sucrose, acted like a regulating 
molecule, allowing the cells a faster division cycle in roots.

Another leaf component that responds to different types of stress is cuticular wax (Shepherd and Griffiths 2006). The interest in this plant structure is mainly due to waxes acting like protective barriers against an ample gamma of abiotic stresses, like the rising $\mathrm{CO}_{2}$, for example. The cuticle, a thin layer that covers the leaves (Fig. 3), is composed of fatty acid polymers of 16 and 18 carbons that form a matrix (cutin), where cellulose microfibrils, oligosaccharides and waxes are found. This layer consists predominantly of longchain hydrocarbons, including alkanes, primary and secondary alcohol, derived aldehydes, ketones, esters and other derived composites, making up the first barrier between plant and environment. A new wax layer can be deposited over the cuticle, forming the epicuticular wax (Willmer and Fricker 1996). Given their biochemical characteristics, the development of an impermeable cuticle was fundamental to the success of plant colonization in Earth's environment, as its primordial function is to control water loss (Shepherd and Griffiths 2006).

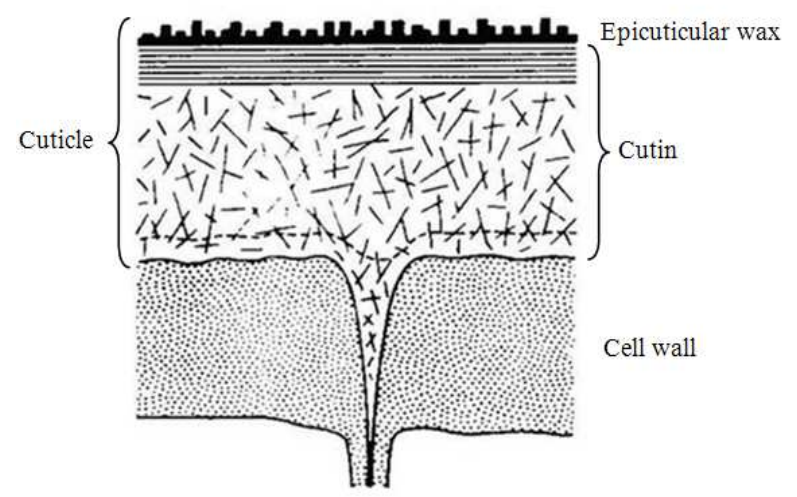

Figure 3 - Illustration of a transversal section of a typical cuticular membrane of a mature leaf (Gülz 1994).

Biosynthesis and the mechanism of cuticular wax deposition involve complex chemical reactions, still not entirely clarified. The initial step is the formation of malonil-CoA from acetil-CoA. The reaction is catalyzed by the multi-functional enzymatic system acetil-CoA carboxilase, with $\mathrm{CO}_{2}$ participation. In the subsequent stage, acyl chains of 16 to 18 carbons are formed and incorporated into the cellular lipid complexes, cutin, suberin and wax components. Then they are hydrolyzed by thioesterases, and the fatty acids formed are transported through the chloroplast membrane. The growth and modifications in the acyl chain occur by means of enzymatic reactions in the cytosol of the epidermal cells. They are, therefore, enzymatic extra-plastidial systems (Gülz 1994). The majority of the wax components come from the reduction reactions, which form primary alcohol, free fatty acids and acetaldehydes, and from decarboxylation, forming alkanes, secondary alcohol and ketones. In the cytosol of epidermal cells, chemical reaction sites are in the endoplasmic reticulum, Golgi apparatus and cellular membrane. The composites formed cross these structures, probably by the means of vesicles, to then deposit themselves on the cuticular surface. The transportation of wax components through the cellular wall and cuticle probably occur by diffusion, via spaces of molecular dimensions and channels that are temporarily open (Kunst and Samuels 2003).

In general, as seen by the scanning electron microscope (SEM), the epicuticular waxes have a microcrystalline structure, sometimes coming from an internal amorphous layer (Hamilton 1995). The aspect of epicuticular waxes is being investigated for various purposes. Barthlott et al. (1998) made high resolution use of SEM to identify and classify 23 types of waxes, considering structures in the form of connecting rods, ribbons, filaments, pipes and plates. Some of these may be related to the presence of specific composites, such as primary and secondary alcohol, esters and others. The chemical base and size of the waxes vary among the species. In Rubus fruticosus, epicuticular waxes consist of free alcohol, alcoholic esters and acetates, with a lower quantity of free fatty acids and alkanes. In Prunus lauroceratus, however, the epicuticular wax consists of aliphatic composites, and the cuticular, primarily, of triterpenoids (Jetter et al. 2000).

Light intensity, temperature and humidity are the factors, which also influence the morphology of the waxes, favoring one structural form, or another. High temperatures, for example, are suitable to structures parallel to the cuticle surface, like plates and scales, while low temperatures, to the rods and pipes. Structures that are already established can change form under certain conditions. Tubular forms are thermodynamically unstable and, under the effect of extreme heat, are modified into planar and stable structures 
(Shepherd and Griffiths, 2006). Different plant responses make these data uncertain, but studies that investigate the effect of elevated $\mathrm{CO}_{2}$ merit attention, because such atmospheric modification will be accompanied by alterations in temperature and humidity, affecting rain cycles and exposure to UV-B rays (Long et al. 2004).

The responses of the content and the composition of leaf waxes exposed to high $\mathrm{CO}_{2}$ are varied. Vanhatalo et al. (2001) found a direct relation between this increase and the wax thickness in Birch pubescens. While in Pinus palustris (Prior et al. 1997) and Agave deserti (Graham and Nobel 1996), there was a wax reduction under the conditions of elevated $\mathrm{CO}_{2}$. There is some contradiction in the reports of plant response exposed to different environmental stress conditions, especially high $\mathrm{CO}_{2}$ concentration.

Another important element involved the response of the plant to environmental alterations is the stomata (Berry et al. 2010), structures formed by two guard cells in the epidermis and essential to the survival of the plants, as they control the input of $\mathrm{CO}_{2}$ and optimize the water use efficiency (WUE). Although they appear in all the organs of the aerial part coated by epidermis, they are most common in the leaves and are found on the abaxial, or adaxial faces, or both. Each stoma originates from a series of divisions that constitute a "stomatal spacing model", controlling its frequency in the epidermis and producing guard cells. With some rare exceptions, stomata are found in all the plant groups, from Bryophyta to Angyosperm. The entrance of water in the guard cells induces the opening of the stoma. This movement occurs throughout the day, depending on the water availability and other factors, which can be environmental (light and temperature, for example), or internal (endogenous levels of sugars, potassium and abscisic acid) (Willmer and Fricker 1996).

The mechanisms involved in opening and closing the stomata have been extensively studied, but the factors that control its functioning are not yet entirely understood. In general, through the stomata, plant leaves that have type $\mathrm{C}_{3}$ photosynthesis (present in the majority of the land plants), permit gaseous exchanges with the environment, while at the same time losing water. This regulation occurs by controlling the opening of the ostiole, which, in turn, is regulated by the modifications in the morphology of guard cells induced by turgor pressure. Collectively, the stomata increase the performance of plants and influence the global carbon and water cycles (Brownlee 2001). Normally, the open period occurs at dawn and continues until midafternoon, with a possible reduction occurring around noon, depending on the atmospheric conditions. This process is fundamental for the growth and maintenance of all plants, as this carbon, assimilated in photosynthesis, is incorporated as cellulose, proteins, nucleic acid and other carbon composites of the plants (Pons and Welschen 2003).

Stomata have piqued the interest of researchers due to the response of the guard cells to an ample variety of environmental stimuli, such as light intensity, humidity and partial pressure of $\mathrm{CO}_{2}$. The stomatal response to $\mathrm{CO}_{2}$ has attracted particular interest in last three decades because (1) its cells respond to the intercellular $\mathrm{CO}_{2}$ concentration $\left(C_{\mathrm{i}}\right)$, which is determined by the concentration of this gas on the leaf surface and by its rate of assimilation in the mesophyll (Mott 1988), and (2) for its potential use as a structure which indicates alterations in the atmospheric concentration of $\mathrm{CO}_{2}$ (Beerling and Woodward 1995; Field et al. 1995; Woodward et al. 2002). The consequences of such alterations for the growth of the plants, distribution of the species and functioning of the ecosystem, make stomatal physiology a focal point in environmental sciences (Morison 1998; Lammertsma et al. 2011), since, annually, $40 \%$ of all atmospheric $\mathrm{CO}_{2}$ (about 300 trillion tons of carbon) pass through the stomata (Lake et al. 2001).

Through plant dynamics models, Cramer et al. (2001) added new data regarding the contribution of stomatal perspiration to the global water and carbon cycles. One may conclude that the largest perspiration rates occur in the tropical forests, with $32 \mathrm{Gt} /$ year of water vapor passing through the stomata, about twice that is contained in the atmosphere (15 Gt/year). In relation to the carbon cycle, the estimate is 120 trillion tons of carbon fixed by photosynthesis, of the 730 trillion found in the atmosphere annually. The study identifies, therefore, the direct relation between the stomatal control, water vapor diffusion and $\mathrm{CO}_{2}$ (Hetherington and Woodward 2003). Several studies have reported a reduction in the number of stomata in the species grown in elevated $\mathrm{CO}_{2}$ (Woodward and Kelly 1995). In this manner, plants grown in reduced $\mathrm{CO}_{2}$ concentration have a higher number of stomata than those grown in 
higher concentrations. Future increases in this concentration can, therefore, result in a decrease of the stomatal density of many species. These observations are consistent with comparisons of stomatal densities of the plants of present time with those of plants collected before the industrial era, a recognized causal agent of the atmospheric increase of this gas (Brownlee 2001).

The first experiments, which investigated the effects of $\mathrm{CO}_{2}$ concentration on the number of stomata were conducted in an enriched atmosphere - $1000 \mathrm{ppm}$ of $\mathrm{CO}_{2}$ (Madsen 1973). The results showed a low stomatal sensitivity, since only one species showed decline. However, the hypothesis that the number of stomata could be modified as a result of alterations in the partial pressure of $\mathrm{CO}_{2}$ was confirmed by Woodward (1987), who compared the stomatal index of the trees from herbarium samples (collected in 1787, in the preindustrial era) with recent samples, finding a $40 \%$ reduction. When these same species were submitted to variations in $\mathrm{CO}_{2}$ concentration, the decrease in stomatal density was $67 \%$.

"Stomatal Density" (SD) is the number of stomata per unit area $\left(\mathrm{mm}^{2}\right)$, but its value may be influenced by the expansion of the epidermal cells. This expansion depends on the variables such as light, temperature, humidity and leaf position on the plant, and is able to conceal the relative signal to stomatal differentiation. The concept "Stomatal Index" (SI) was introduced. SI is the proportion of stomata relative to the number of epidermal cells. The SI was suggested to normalize the effects of the expansion of these cells (Royer 2001). SD and SI were used by Woodward et al. (2002) to explain the possible ecological consequences of elevated $\mathrm{CO}_{2}$ on the plants. The authors concluded that the availability of water, light incidence and hormones when acting together with high $\mathrm{CO}_{2}$, produced distinct responses to those obtained in the experiments when only the $\mathrm{CO}_{2}$ concentration was modified. The recognized reduction of stomata in the majority of the species grown in high $\mathrm{CO}_{2}$ (Pritchard et al. 1999; Wagner et al. 2005) in the experiments of short duration (days, or months) as well as in those carried out on fossil remnants (up to millions of years), configured an evolutionary advantage for itself which should not only imply better water use efficiency, given that this reduction acted on other physiological effects in plants. In a simple, however, classic and enlightening experiment, Lake et al. (2001) proved that mature Arabidopsis thaliana leaves detected the changes in the atmospheric $\mathrm{CO}_{2}$ concentration and light intensity, and sent them via long distance chemical signals to developing leaves. In the same manner, developing leaves seem to be capable to detect these signals and respond, modifying the process of stomatal differentiation. As a result, the number of stomata on the youngest leaves could be different than that of stomata found on the mature leaves, suggesting an important ecological connection in the reactions induced by the light and $\mathrm{CO}_{2}$.

\section{Stomatal development}

The asymmetric cellular divisions, which define the number and organization of stomata on leaf epidermis, are commanded by intrinsic signals of local action (among the epidermis cells), or by the distance (of mature leaves to those that are developing), and by extrinsic factors such as light, water and atmospheric $\mathrm{CO}_{2}$. Studies have demonstrated the presence of superficial cellular receptors and intracellular signaling molecules in perception and response to these factors (Bergmann 2006).

During leaf development, a pattern of cellular divisions, regulated by the genetic and environmental signals, determines the appearance of the stomata. Even though the stomatal density is varied, stomata are separated by at least one pavement cell - the most numerous of the epidermal cells, with varied functions, such as water storage in their big vacuoles and protection against the insect attack and pathogens. This spacing, referred in Arabidopsis as 'one-cell spacing', is, probably, an adaptive solution to minimize the mechanical interferences between the adjacent stomata, thus optimizing gas diffusion. It appears when a new asymmetric division is initiated near a stoma. Stomatal development has been the topic of extensive research in recent years, mostly with Arabidopsis cells. To form the stoma, the first asymmetric division occurs in the meristemoid mother cell (MMC), producing a smaller cell, meristemoid (M), which is converted into a guard mother cell (GMC). Later, a symmetric division of the GMC forms the two guard cells, which make up the stomata (Bergmann and Sack 2007).

Some regulators of stomatal development, such as receiving proteins and MAP kinases (Mitogenactivated protein), act as inhibitors in the appearance of new stomata. This process has been clarified by recent publications upon identifying 
the essential transcription factors in stomatal differentiation (Gray 2007). SPEECHLESS, MUTE and FAME are the members of an Arabidopsis thaliana protein family with distinct expression and specific function in this differentiation. SPEECHLESS proteins participate in the first asymmetric division, initiating the lineage of stomatal cells in the epidermal layer under development. Mutant plants for the SPEECHLESS gene do not produce meristemoid cells, guard cells, or stomata. Their growth is slower and they do not reach maturity. The MUTE gene is required in the final stages of asymmetric division and at the beginning of differentiation. Mutant plants that lose the expression of this gene produce meristemoid cells, but not stomata, as those that have excessive expression, and an epidermis basically made up of stomata (Bird and Gray 2003).

The FAME gene is specifically expressed in the guard mother cells and directly participates in the differentiation from, which stomata originate. Mutant plants for this gene have groups of immature guard cells, incompletely differentiated and non-functional (Ohashi-Ito and Bergmann 2006; MacAlister et al. 2007) Similar to FAME, two other transcription factors - FOUR LIPS e $M Y B 88$ - seem to be involved in the differentiation of guard cells, even though the first one acts independently of the others (Gray 2007). The progress in the field of stomatal development has identified the genes that control the production and spacing of stomata in Arabidopsis. These genes are receptors, proteases and kinases, and act primarily in modulating the number and location of the asymmetric divisions of the stomatal cellular lineage. Bergmann and Sack (2007) described the participation of these genes according to the phase in which they participated.

The ERECTED (ER) gene codifies a receptor that contains a rich extracellular domain in leucine (LRR), a transmembrane domain and a cytoplasmatic kinase (RLK). This protein participates in several processes, including the growth and development, as well as responses to biotic and abiotic stress. Differences in transpiration efficiency, a phenomenon directly linked to stomatal behavior, are related to the $E R$ gene. It is possible that $E R$ kinases and other proteins have participated in stomatal development processes, transpiration and photosynthesis, and that the changes in the transpiration efficiency of er mutants are an indirect consequence of the stomatal development, that is, modified plant morphology, leaf thickness and stomatal density (Masle et al. 2005; Bergmann 2006). TOO MANY MOUTHS (TMM), another gene of initial action, codifies the surface receptors in meristemoids cells and guard mother cells, but are absent in totally differentiated guard cells. In Arabidopsis, more than two hundred kinases share a common structure of extracellular domain rich in leucin, a single transmembrane domain and one cytoplasmic kinase. Mutations of this gene provoke alterations in all types of asymmetric divisions of the stomatal lineage, forming an excess of stomata in the leaves and indicating that the function of this gene is to restrain divisions. In mutants tmm-1, errors were observed in the asymmetry of the divisions, essential to the creation of spacing, and in amplifying divisions, which led it to the premature conversion of meristemoid cells into guard mother cells. Therefore, proteins of the ER and TMM families control the asymmetric divisions of stomatal development. YODA is a member of the MAP class (mitogen-actived protein) kinases, which has long N-terminal extension and negative regulatory activity. Mutant plants with proteins lacking this extension have leaves with an epidermis composed only of pavement cells. After the initial phase of asymmetric divisions and establishing the spacing model, the cellular program is directed toward symmetric divisions and differentiation. The known genes that act during this phase participate in cellular proliferation, in GMC cytokinesis and regulate guard cell differentiation (Bergmann and Sack 2007).

The HIC (HIgh Carbon dioxide) gene, recently discovered in Arabidopsis and a landmark in genetic research of stomata, codifies a negative regulator (inhibitor) of stomatal development, which reacts to the $\mathrm{CO}_{2}$ concentration. There are many uncertainties in this area and the mechanism by which $H I C$ affects the stomatal development in response to $\mathrm{CO}_{2}$ is not yet known, but studies suggests that this gene codifies a 3-cetoacil CoA synthase, an enzyme involved in the synthesis of very long chain fatty acids (VLCFA). Mutant plants for this gene exhibit up to a $42 \%$ increase of the stomatal index when exposed to twice as much atmospheric concentration of $\mathrm{CO}_{2}$. The explanation would be in alterations in the permeability of the extracellular matrix of guard cells, which then would modify the diffusion of a molecule stimulated by the high $\mathrm{CO}_{2}$, such 
molecule being responsible for the control of the stomatal development. With the diffusion compromised, there would not be inhibition to the neighboring cell differentiation, giving origin to a new guard cell. This was the first plant development gene identified that responded to global atmospheric changes (Gray et al. 2000).

These studies ratify the involvement of the cuticle in the apoplastic movement of signals in the leaf epidermis, which determine the number of stomata for the plant. The more precise clarification of this mechanism must be a key issue of plant biology over the next years, since one of the main components of the greenhouse effect passes through the ostioles, a topic of scientific concern and recent international discussion, even though Arrhenius made this known over one century ago.

\section{ACKNOWLEDGMENTS}

I would like to thank Professor Marcos S. Buckeridge for his valuable teaching in the study. This study was supported by Brazilian Government's Agency (CAPES), State University of Campinas (UNICAMP) and Institute of Botany of São Paulo (IBt).

\section{REFERENCES}

Aidar MPM, Martinez CA, Costa AC, Costa PMF, Dietrich SMC, Buckeridge MS. Efeito do enriquecimento do $\mathrm{CO}_{2}$ atmosférico sobre o estabelecimento de plântulas de jatobá, Hymenaea courbaril L. (Leguminosae, Caesalpinoideae). Bio Neot. 2002; 2(1): 1-10.

Ainsworth EA, Long SP. What have we learned from 15 years of free air- $\mathrm{CO}_{2}$ enrichment (FACE)? A meta-analytic review of the responses of photosynthesis, canopy properties and plant production to rising $\mathrm{CO}_{2}$. New Phytol. 2005; 165: 351-372.

Aranda X, Agusti C, Joffre R, Fleck I. Photosynthesis, growth and structural characteristics of holm oak resprouts originated from plants grown under elevated $\mathrm{CO}_{2}$. Physiol Plant. 2006; 128: 302-312.

Barthlott W, Neinhuis C, Cutler D, Ditsch F, Meusel I, Theisen I, et al. Classification and terminology of plant epicuticular waxes. Bot J Linean Soc. 1998; 126, 237-260.

Beerling DJ, Woodward FI. Stomatal responses of variegated leaves to $\mathrm{CO}_{2}$ enrichment. Ann Bot. 1995; 75: 507-511.
Beerling DJ, Royer DL. Reading a $\mathrm{CO}_{2}$ signal from fossil stomata. New Phytol. 2002; 153: 387-397.

Bergmann D. Stomatal development: from neighborly to global communication. Curr Opin Plant Biol. 2006; 9: 478-483.

Bergmann DC, Sack FD. Stomatal development. Ann Rev Plant Biol. 2007; 58: 163-181.

Berry JA, Beerling DJ, Franks PJ. Stomata: key players in the Earth system, past and present. Curr Opin Plant Biol. 2010; 13: 233-240.

Bird SM, Gray JE. Signals from the cuticle affect epidermal cell differentiation. New Phytol. 2003; 157: 9-23.

Brownlee C. The long and the short of stomatal density signals. Trends Plant Sci. 2001; 6(10): 441-442.

Buckeridge MS, Aidar MPM. Carbon sequestration in the rain forest: Alternatives using environmentally friendly biotechnology. Bio Neot. 2002; 2(1): 1-4.

Ceulemans R, Mousseau M. Effects of elevated atmospheric $\mathrm{CO}_{2}$ on woody plants. New Phytol. 1994; 127(3): 425-446.

Cramer W, Bondeau A, Woodward FI, Prentice IC, Betts RA, Brovkin $\mathrm{V}$, et al. Global response of terrestrial ecosystem structure and function to $\mathrm{CO}_{2}$ and climate change: results from six dynamic global vegetation models. Global Change Biol. 2001; 7: 357-373.

El Kohen A, Venet L, Mousseau M. Growth and photossyntesis of two deciduous forest tree species exposed to elevated carbon dioxide. Func Ecol. 1993; 7: 480-486.

EPA. United State Environmental Protection Agency. Accessed in 2012 Feb. 13. Available from: www.epa.gov/climatechange.

Ewert, F. Modelling plant responses to elevated $\mathrm{CO}_{2}$ : How important is leaf area index? Ann Bot. 2004; 93: 619-627.

Ferguson SD, Nowak RS. Transitory effects of elevated atmospheric $\mathrm{CO}_{2}$ on fine root dynamics in an arid ecosystem do not increase long-term soil carbon input from fine root litter. New Phytol. 2011; 190: 953-967.

Field CB, Jackson RB, Mooney HA. Stomatal responses to increased $\mathrm{CO}_{2}$ : implications from the plant to the global scale. Plant Cell Environ. 1995; 18: 1214-1225.

Forster P, Ramaswamy V, Artaxo P, Berntsen T, Betts R, Fahey D, et al. Changes in atmospheric constituents and in radiative forcing. In: Climate Change 2007: The Physical Science Basis. Contribution of Working Group I to the Fourth Assessment Report of the Intergovernmental Panel on Climate Change, ed. Cambridge University Press, Cambridge, United Kingdom and New York, NY, USA. 2007. p. 133-153.

Gardner SDL, Taylor G, Bosac C. Leaf growth of hybrid poplar following exposure to elevated $\mathrm{CO}_{2}$. New Phytol. 1995; 131: 81-90. 
Gitay H, Suárez A, Watson RT, Dokken DJ. Climate change and biodiversity. In: Intergovernmental Panel on Climatic Change technical paper V. United Nations Environment Programme/World Meteorological Organization, Genebra. 2002.

Graham EA, Nobel PS. Long-term effects of a doubled atmospheric $\mathrm{CO}_{2}$ concentration on the CAM species Agave deserti. J Exp Bot. 1996; 47: 61-69.

Gray JE, Holroyd GH, van der Lee FM, Bahrami AR, Sijmons PC, Woodward FI, et al. The HIC signaling pathway links $\mathrm{CO}_{2}$ perception to stomatal development. Nature. 2000; 408: 713-716.

Gray JE. Plant development: three steps for stomata. Curr Biol. 2007; 17: 213-215.

Gülz PG. Epicuticular leaf waxes in the evolution of the plant kingdom. J Plant Physiol.1994; 143: 453-464.

Hamilton RJ. Waxes: Chemistry, molecular biology and functions. The Oily Press, Scotland; 1995.

Hetherington AM, Woodward FI. The role of stomata in sensing and driving environmental change. Nature. 2003; 424: 901-908.

Hugues L. Biological consequences of global warming: is the signal already apparent? Tree. 2000; 15(2): 5661.

Jarvis AJ, Mansfield TA, Davies WJ. Stomatal behavior, photosynthesis and transpiration under rising $\mathrm{CO}_{2}$. Plant Cell Environ. 1999; 22: 639-648.

Jetter R, Schäffers S, Riederer M. Leaf cuticular waxes are arranged in chemically and mechanically distinct layers: evidence from Prunus laurocerasus L. Plant Cell Environ. 2000; 23: 619-628.

Jordan GJ. A critical framework for the assessment of biological palaeoproxies: predicting past climate and levels of atmospheric $\mathrm{CO}_{2}$ from fossil leaves. New Phytol. 2011; 192(1), 29-44.

Kandel R. Le réchauffement climatique. Presses Universitaires de France, Paris; 2002.

Kunst L, Samuels AL. Biosysnthesis and secretion of plant cuticular wax. Prog Lipid Res. 2003; 42: 51-80.

Latif M. Uncertainty in climate change projections. $J$ Geo Exp. 2011; 110: 1-7.

Lake JA, Quick WP, Beerling DJ, Woodward FI. Plant development. Signals from mature to new leaves. Nature. 2001; 411: 154.

Lammertsma EI, de Boer HJ, Dekker SC, Dilcher DL, Lotter AF, Wagner-Cremer F. Global $\mathrm{CO}_{2}$ rise leads to reduced maximum stomatal conductance in Florida vegetation. Proc Natl Acad Sci USA. 2011; 108(10): 4035-4040.

Le Treut H, Somerville R, Cubasch U, Ding Y, Mauritzen C, Mokssit A, et al. Historical overview of climate change. In: Climate Change 2007: The Physical Science Basis. Contribution of Working Group I to the Fourth Assessment Report of the Intergovernmental Panel on Climate Change, Cambridge University Press, Cambridge, United Kingdom and New York. 2007.
Leakey ADB, Ainsworth EA, Bernacchi CJ, Rogers A, Long SP, Ort DR. Elevated $\mathrm{CO}_{2}$ effects on plant carbon, nitrogen, and water relations: six important lessons from FACE. J Exp Bot. 2009; 60(10): 28592876.

Lin Y, Medlyn BE, Ellsworth DS. Temperature responses of leaf net photosynthesis: the role of component processes. Tree Physiol. 2012; 32(2): 219231.

Long SP, Ainsworth EA, Rogers A, Ort DR. Rising atmospheric carbon dioxide: plants FACE the future. Annu Rev Plant Biol. 2004; 55: 591-628.

MacAlister CA, Ohashi-Ito K, Bergmann DC. Transcription factor control of asymmetric cell divisions that establish the stomatal lineage. Nature. 2007; 445: 537-540.

Madsen E. Effects of $\mathrm{CO}_{2}$ concentrations on the morphological, histological and cytological changes in tomato plants. Acta Agric Scand. 1973; 23: 241246.

Masle J, Gilmore SR, Farquhar GD. The ERECTA gene regulates plants transpiration efficiency in Arabidopsis. Nature. 2005; 436: 866-780.

Morison JIL. Stomatal response to increased $\mathrm{CO}_{2}$ concentration. J Exp Bot. 1998; 49: 443-452.

Mott KA. Do stomata respond to $\mathrm{CO}_{2}$ concentrations other than intercellular? Plant Physiol. 1988; 86: 200203.

Mousseau M, Enoch ZH. Carbon dioxide enrichment reduces shoot growth in sweet chestnut (Castanea sativa Mill). Plant Cell Environ. 1989; 12: 927-934.

Newman L, Kiefer T, Otto-Bliesner B, Wanner H. The science and strategy of the Past Global Changes (PAGES) project. Curr Opin Environ Sust. 2010; 2: 193-201.

Ohashi-Ito K, Bergmann DC. Arabidopsis FAMA controls the final proliferation/differentiation switch during stomatal development. Plant Cell. 2006; 18: 2493-2505.

Okada M, Lieffering M, Nakamura H, Yoshimoto M, Kim HY, Kobayashi K. Free-air $\mathrm{CO}_{2}$ enrichment (FACE) using pure $\mathrm{CO}_{2}$ injection: system description. New Phytol. 2001; 150: 251-260.

Peppe DJ, Royer DL, Cariglino B, Oliver SY, Newman S, Leight E, et al. Sensitivity of leaf size and shape to climate: global patterns and paleoclimatic applications. New Phytol. 2011; 190: 724-739.

Petterson R, McDonald AJS, Stadenberg I. Response of small birch plants (Betula pendula Roth.) at optimal nutrition. Plant Cell Environ. 1993; 16: 1115-1121.

Phillips OL, Malhi Y, Higuchi N, Laurance WF, Nunez PV, Vasquez RM et al. Changes in carbon balance of tropical forests: evidence from long-term plots. Science. 1998; 282: 439-441.

Pinkard EA, Beadle CL, Mendham DS, Carter J, Glen M. Determining photosynthetic responses of forest species to elevated [CO2]: Alternatives to FACE. Forest Ecol Manag. 2010; 260: 1251-1261. 
Pons TL, Welschen RAM. Midday depression of net photosynthesis in the tropical rainforest tree Eperua grandiflora: contributions of stomatal and internal conductances, respiration and Rubisco functioning. Tree Physiol. 2003; 23: 937-947.

Poorter H. Interspecific variation in the growth response of plants to an elevated ambient $\mathrm{CO}_{2}$ concentration. Vegetatio. 1993; 104/105: 77-97.

Prentice IC. The carbon cycle and atmospheric carbon dioxide. In: Climate change 2001: The Scientific Basis (ed. IPCC). Cambridge University Press. 2001. p. 183-237.

Prior SA, Pritchard SG, Runion GB, Rogers HH, Mitchell RJ. Influence of atmospheric $\mathrm{CO}_{2}$ enrichment, soil $\mathrm{N}$ and water stress on needle surface wax formation in Pinus palustris (Pinaceae). Am J Bot. 1997; 84: 1070-1077.

Pritchard SG, Rogers HH, Prior SA, Peterson CM. Elevated $\mathrm{CO}_{2}$ and plant structure: a review. Global Change Biol. 1999; 5: 807-837.

Ranasinghe S, Taylor G. Mechanism for increased leaf growth in elevated $\mathrm{CO}_{2}$. J Exp Bot. 1996; 47: 349358.

Raupach MR, Marland G, Ciais P, Le Quéré C, Canadell JP, Klepper G, et al. Global and regional drivers of accelerating $\mathrm{CO}_{2}$ emissions. Proc Natl Acad Sci USA. 2007; 104(24): 10288-10293.

Riikonen J, Percy KE, Kivimäenpää M, Kubiske ME, Nelson ND, Vapaavuori E, et al. Leaf size and surface characteristics of Betula papyrifera exposed to elevated $\mathrm{CO}_{2}$ and $\mathrm{O}_{3}$. Environ Pollut. 2010; 158: 1029-1035.

Rogers HH, Peterson CM, McCrimmon JN, Cure JD. Response of plant roots to elevated atmospheric carbon dioxide. Plant Cell Environ. 1992; 15: 749752.

Royer DL. Stomatal density and stomatal index as indicator of paleoatmospheric $\mathrm{CO}_{2}$ concentration. $\mathrm{Rev}$ Palaeobot Palynol. 2001; 114: 1-28.

Shepherd T, Griffiths DW. The effects of stress on plant cuticular waxes. New Phytol. 2006; 171: 469-499.
Smith AM, Stitt M. Coordination of carbon supply and plant growth. Plant Cell Environ. 2007; 30: 11261149.

Souza L, Belote RT, Kardol P, Weltzin JF, Norby RJ. $\mathrm{CO}_{2}$ enrichment accelerates successional development of an understory plant community. J Plant Ecol. 2010; 3(1): 33-39.

Sprugel DG, Hinckley TM, Schaap W. The theory and practice of branch autonomy. Ann Rev Ecol System. 1991; 22: 309-334.

Taylor G, Ranasinghe S, Bosac C, Gardner SDL, Ferris R. Elevated $\mathrm{CO}_{2}$ and plant growth: cellular mechanisms and responses of whole plants. J Exp Bot. 1994; 45: 1761-1774.

Teng N, Wang J, Chen T, Wu X, Wang Y, Lin J. Elevated $\mathrm{CO}_{2}$ induces physiological, biochemical and structural changes in leaves of Arabidopsis thaliana. New Phytol. 2006; 172: 92-103.

Vanhatalo R, Huttunen S, Back J. Effects of elevated $\left[\mathrm{CO}_{2}\right]$ and $\mathrm{O}_{3}$ on stomatal and surface wax characteristics on leaves of pubescent birch grown under field conditions. Trees-Struct Funct. 2001; 15: 304-313.

Wagner F, Dilcher DL, Visscher H. Stomatal frequency responses in hardwwod-swamp vegetation from Florida during a 60-year continuous $\mathrm{CO}_{2}$ increase. Am J Bot. 2005; 92(4): 690-695.

Willmer C, Fricker M. Stomata. 2nd ed. Chapman \& Hall; 1996.

Woodward FI. Stomatal numbers are sensitive to increases in $\mathrm{CO}_{2}$ from pre-industrial levels. Nature. 1987; 327: 617-618.

Woodward FI, Kelly CK. The influence of $\mathrm{CO}_{2}$ concentration on stomatal density. New Phytol. 1995; 131: 311-327.

Woodward FI, Lake JA, Quick WP. Stomatal development and $\mathrm{CO}_{2}$ : ecological consequences. New Phytol. 2002; 153: 477-484. 